\title{
PERBEDAAN HARMONI SOSIAL PENGHUNI RUMAH SUSUN DAN PENGHUNI RUMAH TAPAK DI KAWASAN TEBET, JAKARTA
}

\author{
The Difference of Social Harmony between the Inhabitants of Flats \\ and Landed Housing in Tebet Area, Jakarta
}

\author{
Hanny Wahidin Wiranegara ${ }^{1}$, Putri Arninda ${ }^{1}$ dan Yosua Harefa ${ }^{1}$
}

\begin{abstract}
Abstrak: Pembangunan perumahan perlu diarahkan pada terbentuknya komunitas-spasial, dicirikan adanya ikatan antarpenghuni dan ikatan dengan tempat tinggalnya. Fenomena ke luarnya penghuni dapat disebabkan rendahnya harmoni sosial atau kondisi fungsional perumahannya. Harmoni sosial menunjukkan kondisi hubungan antarpenghuni yang meliputi tiga dimensi: ikatan nilai, ikatan perasaan, dan ikatan/tindakan bersama. Harmoni sosial merupakan unsur penting dalam perwujudan komunitas. Cerai berainya penghuni terjadi baik di perumahan susun maupun di perumahan tapak. Tujuan penelitian adalah teridentifikasinya perbedaan harmoni sosial penghuni rumah susun dengan penghuni rumah tapak, serta teridentifikasinya unsur-unsur kondisi fungsional perumahan yang mempengaruhi harmoni sosial. Metode penelitian digunakan survey-angket. Pertanyaan angket disusun dalam skala Likert. Kawasan Tebet dipilih karena di dalamnya bercampur rumah tapak dan rumah susun, sementara unsur-unsur lain dapat diasumsikan homogen. Hasil menunjukkan terdapat perbedaan harmoni sosial antara penghuni rumah tapak dan rumah susun. Harmoni sosial di rumah susun lebih rendah. Unsur kondisi fungsional perumahan pada ke dua tipe perumahan yang mempengaruhi harmoni sosial adalah fungsi ekonomi dan fungsi pelayanan. Oleh karena itu, dalam perencanaan perumahan selain tersedianya fasilitas sosial-ekonomi dan utilitas, penting pula diperhatikan berjalannya fungsifungsi tersebut agar tercipta harmoni sosial di antara penghuninya yang selanjutnya dapat mewujud sebagai suatu komunitas.
\end{abstract}

\section{Kata kunci: harmoni sosial, kondisi fungsional, rumah susun, rumah tapak}

Abstract: Housing development has to be directed to establish a spatial community characterized by the bond among members and place attachment to their living space. The moving some of the inhabitants outside can be caused by low social harmony or low functional conditions of their housing. Social harmony is the condition of bonding among inhabitants consists of a bond of value, a bond of feeling, and a common action. Social harmony is an important element to establish a spatial community. The moving dwellers to outward occur both in landed housing and the flats. The research aims are to identify the difference of social harmony between the inhabitants of flats and landed houses, as well as to identify the elements of functional conditions of housing that affect social harmony. The research design was used questionnaire survey using Likert's scale. Area of Tebet was chosen as the study area due to there are the landed houses and the flats inside and it could be assumed that other elements are homogenous. The results showed that there was the difference of social harmony between the two types of housing. Social harmony in flats was lower. Two kinds of housing functions affecting social harmony in both types were the economic function and service function. Hence, in housing planning besides the availability of social-economic facilities and utilities, also important to be considered about

\footnotetext{
${ }^{1}$ Program Studi Perencanaan Wilayah dan Kota, FALTL, Universitas Trisakti, Jakarta
} 
how these function running well in order to keep the social harmony among its inhabitants next come into being as a community.

Keywords: functional conditions, flats, landed housing, social harmony

\section{PENDAHULUAN}

Pembangunan perumahan harus ditujukan pada terbentuknya komunitas (Budihardjo, 1997; Tjahjono, 2008), yakni suatu kondisi yang dapat digambarkan oleh adanya ikatan antarpenghuninya serta ikatan antara penghuni dengan tempat tinggalnya. Ini menunjuk pada komunitas-spasial yang dapat dibedakan dari komunitas-aspasial. Untuk membentuk komunitas di perumahan dibutuhkan harmoni sosial. Hal ini bermakna bahwa perumahan yang dibangun harus dapat berfungsi memfasilitasi penghuni meraih harmoni sosial antarmereka. Maknanya, terbentuknya harmoni sosial perlu dipertimbangkan dalam pembangunan perumahan, baik pada perumahan tapak maupun perumahan susun.

Wiranegara (2015) menunjukkan kondisi fungsional rumah susun memiliki kontribusi pada terbentuknya harmoni sosial penghuninya. Sementara harmoni sosial di perumahan tapak belum diketahui. Harmoni sosial adalah suatu kondisi hubungan antarmanusia yang dapat mengarah pada kesatuan komunitas yang fungsional. Perumahan yang tidak berfungsi dengan baik menunjukkan tidak adanya atau lemahnya ikatan di antara para penghuninya. Fenomena banyaknya penghuni berpindah ke tempat lain menunjukkan lemahnya ikatan di antara mereka. Sesungguhnya, jika anggota komunitas tercerai berai tidak dapat lagi disebut sebagai komunitas (Koentjaraningrat, 1977). Akibat anggota komunitas yang tercerai berai maka akan terjadi penurunan kualitas lingkungan perumahan yang bersangkutan. Kondisi seperti ini dapat dijumpai baik pada perumahan tapak maupun rumah susun. Oleh karena itu, perlu diketahui harmoni sosial penghuni rumah tapak maupun penghuni rumah susun dan unsur kondisi fungsional perumahan yang mempengaruhi harmoni sosial pada ke dua tipe perumahan tersebut.

Kawasan Tebet merupakan salah satu kawasan perumahan yang mengalami perkembangan jumlah penduduk dan hunian yang pesat dari tahun ke tahun. Titik awal perkembangan kawasan ini terjadi pada tahun 1960, pada masa pembangunan kawasan olahraga Gelora Bung Karno. Pada saat itu terjadi relokasi penduduk besar-besaran ke kawasan Tebet yang merupakan awal terjadinya perkembangan perumahan di kawasan tersebut. Kawasan Tebet menarik diteliti karena perumahan di wilayah ini sudah berlangsung cukup lama sehingga dapat diasumsikan sudah terbentuk adanya ikatan-ikatan di antara penghuninya. Selain itu, di kawasan ini dijumpai adanya campuran tipe perumahan, yaitu adanya blok rumah susun yang berbaur dengan perumahan tapak, sehingga cocok dijadikan kasus untuk melihat perbedaan harmoni sosial antara penghuni perumahan susun dan perumahan tapak yang berada dalam konteks yang diasumsikan homogen.

Tujuan penelitian ini adalah: teridentifikasi ada tidaknya perbedaan harmoni sosial penghuni di rumah susun dan di rumah tapak dan teridentifikasinya unsur-unsur kondisi fungsional perumahan (rumah susun dan rumah tapak) yang mempengaruhi harmoni sosial penghuninya di Kawasan Tebet.

\section{Harmoni Sosial}

Terciptanya harmoni sosial di antara penghuni suatu perumahan akan mempengaruhi keberfungsian suatu komunitas. Tanpa adanya harmoni sosial di antara penghuni akan sulit bagi suatu komunitas untuk berfungsi dengan baik. Besar kecilnya harmoni sosial ini dipengaruhi oleh kondisi perumahan yang mereka tempati. Berdasarkan Wiranegara $(2013,2015)$, harmoni sosial dipahami sebagai kondisi hubungan antarmanusia 
yang dapat mengarah pada kesatuan komunitas yang fungsional dilihat dari tiga dimensi hubungan berikut: 1) harmoni dalam nilai; 2) harmoni dalam perasaan; 3) harmoni dalam tindakan. Penelitian ini merupakan penelitian lanjutan dengan menggunakan indikator harmoni sosial yang telah digunakan pada penelitian Wiranegara (2015).

Harmoni dalam nilai merupakan unsur harmoni sosial yang terdalam dan memerlukan waktu lama untuk membangunnya. Dapat mewujud dalam hitungan puluhan tahun. Berganti-gantinya penghuni menyulitkan terbentuknya harmoni dalam nilai, apalagi dengan banyaknya perbedaan latar belakang antar penghuni di suatu perumahan. Harmoni dalam nilai dapat dijumpai pada penghuni perumahan yang sudah bersama-sama hidup selama puluhan tahun di perumahan yang sama, seperti perumahan di kawasan Tebet. Pada permukiman kumuh perkotaan yang penghuninya telah puluhan tahun hidup bersama-sama menunjukkan adanya harmoni dalam nilai yang lebih kuat dibanding penghuni perumahan terencana yang penghuninya berasal dari berbagai latar belakang yang berbeda, di perumahan terencana hanya dijumpai kesamaan kemampuan finansial antarpenghuni. Untuk mengukur harmoni dalam nilai digunakan indikator yang telah diturunkan dari sepuluh nilai harmoni yang meliputi: kesatuan, daya tahan, ketertiban, welas asih, saling menghargai, persamaan derajat, keadilan, kerjasama, saling memahami, dan komunikasi yang efektif (Wiranegara, 2013). Seluruh nilai harmoni ini menjadi dasar penyusunan indikator harmoni dalam nilai yang telah dijabarkan dan disusun menjadi butir-butir pertanyaan dalam angket dalam penelitian Wiranegara (2015). Pada penelitian ini digunakan hasil tersebut dengan beberapa modifikasi terutama terkait angket bagi penghuni rumah tapak.

Berdasarkan Wiranegara (2013, 2015), harmoni dalam perasaan antarsesama penghuni perumahan dapat ditunjukkan oleh adanya perasaan sebagai bagian dari kelompok, seperti ditunjukan oleh rasa ke-kita-an. Ikatan antarpenghuni yang menunjukkan adanya rasa ke-kita-an (we ness) dapat ditunjukkan dari penggunaan kata "kita" lebih banyak dipakai dibanding kata "saya". Rasa ke-kita-an ini dapat ditunjukkan pula oleh adanya rasa semangat sebagai bagian dari satu komunitas, adanya rasa saling ketergantungan timbal balik, atau rasa kewajiban pada kelompok/komunitas. Jadi, rasa kekitaan adalah perasaan sebagai satu kelompok, dapat terwujud di lingkungan perumahan dalam bentuk kelompok pertemanan/persahabatan/persaudaraan. Rasa saling bergantung adalah perasaan saling membutuhkan satu sama lain secara timbal balik yang seimbang. Rasa kewajiban pada kelompok adalah perasaan adanya keharusan pada diri untuk memajukan kelompok secara sukarela tanpa mengharapkan imbalan. Sama seperti harmoni dalam nilai, harmoni dalam perasaan akan muncul dan melekat pada sesama penghuni yang sama-sama telah lama hidup bersama atau sudah muncul ikatan nilai di antara mereka. Sama halnya dengan harmoni dalam nilai, indikator untuk mengukur harmoni dalam perasaan digunakan hasil penelitian Wiranegara (2015).

Harmoni dalam tindakan adalah kebersamaan dalam melakukan kegiatan bersama yang dapat didasari oleh ada atau tidaknya harmoni dalam nilai dan atau harmoni dalam perasaan. Harmoni dalam tindakan merupakan dimensi harmoni sosial yang paling dangkal. Hal ini diukur melalui berbagai kegiatan bersama yang dilakukan oleh penghuni, seperti kegiatan untuk kesejahteraan bersama; kegiatan sosial-budaya; serta kegiatan kerjabakti. Disebut sebagai ikatan yang dangkal (shallow) karena dapat saja berlangsung kegiatan bersama yang diikuti oleh sesama penghuni tetapi di antara mereka tidak ada ikatan nilai dan atau ikatan perasaan. Jadi, hanya sekedar ikut dalam kegiatan bersama karena berbagai alasan, di luar adanya ikatan nilai atau ikatan rasa. Sebagai contoh kegiatan kerjabakti membersihkan lingkungan perumahan dapat saja berlangsung walaupun tidak ada harmoni dalam perasaan maupun harmoni dalam nilai antarpenghuninya. Sebaliknya, jika terdapat harmoni dalam nilai maka harmoni dalam perasaan akan terwujud dan termanifestasi pada harmoni dalam tindakan. Untuk 
mengukur harmoni dalam tindakan digunakan indikator yang digunakan pada Wiranegara (2015).

\section{Rumah Susun dan Rumah Tapak}

Mengacu pada Undang-undang Nomor 20 Tahun 2011, rumah susun adalah bangunan gedung bertingkat yang mengandung sejumlah satuan rumah susun (sarusun) yang disusun secara horisontal dan vertikal dan dapat dimiliki dan digunakan secara terpisah. Sarusun merupakan unit tempat tinggal penghuni seperti unit rumah pada perumahan tapak. Selain mengandung sarusun, rumah susun memiliki elemen-elemen seperti bagian bersama, benda bersama, dan tanah bersama. Tanah bersama adalah sebidang tanah tempat rumah susun berdiri yang batasnya sesuai dengan yang tercantum dalam izin mendirikan bangunan (IMB). Benda bersama adalah bangunan berbagai fasilitas yang dimiliki bersama untuk dipakai bersama. Benda bersama meliputi sarana pendidikan (umumnya tersedia play group, taman kanak-kanak, tempat pengajian anak, dll), sarana perdagangan (warung, toko, mini market), sarana kesehatan (praktek dokter, klinik), sarana peribadatan (mushola atau mesjid), sarana bermain anak, sarana parkir kendaraan, sarana pelayanan jasa dan sarana komersial lainnya. Bagian bersama adalah bagian dari rumah susun yang dimiliki secara tidak terpisah untuk pemakaian bersama dalam kesatuan fungsi dengan satuan-satuan rumah susun. Contoh bagian bersama adalah: tangga (atau lift) sebagai alat pergerakan vertikal; jaringan utilitas meliputi sistem jaringan energi listrik, gas, air bersih, pembuangan air kotor, penangkal petir, sistem pengelolaan pembuangan sampah, sistem pemadam kebakaran; sistem-sistem lainnya yang diperlukan.

Dalam Undang-undang Nomor 20 Tahun 2011 disebutkan terdapat empat jenis rumah susun, yaitu: rumah susun umum; rumah susun khusus; rumah susun negara; dan rumah susun komersial. Ke empat jenis rumah susun tersebut memiliki kelompok sasaran berbeda. Pada penelitian ini diarahkan pada rumah susun umum. Rumah susun umum diselenggarakan untuk memenuhi kebutuhan rumah bagi masyarakat berpenghasilan rendah (MBR).

Rumah tapak atau landed house adalah rumah yang bangunannya menapak langsung dengan tanah. Rumah tapak dapat berupa rumah tunggal atau rumah gandeng/deret. Rumah tunggal adalah bangunan tempat tinggal yang terpisah dengan rumah lain di sampingnya. Rumah gandeng/rumah deret adalah rumah yang dindingnya bergandengan dengan rumah lain. Ciri utama rumah tapak selain bangunannya menapak langsung dengan tanah, hak kepemilikannya juga bersifat tunggal, bukan strata title seperti di rumah susun.

Seperti telah dikemukakan sebelumnya, dalam sebuah bangunan rumah susun terdapat banyak unit sarusun/rumah yang dimiliki masing-masing penghuni serta terdapat bagian bangunan yang dimiliki secara bersama-sama oleh para penghuni. Jadi, dalam bangunan rumah susun ada hak kepemilikan bersama, yaitu hak atas tanah bersama, benda bersama, atau ruang bersama, sehingga penghuni di rumah susun lebih dituntut lebih tingginya harmoni sosial.

\section{Fungsi-fungsi Perumahan}

Hal penting dipertimbangkan dalam penyediaan perumahan adalah kondisi fungsionalnya. Berdasarkan hasil penelitian Wiranegara (2015), terdapat lima fungsi rumah susun terkait dengan penghuninya, yaitu 1) fungsi pelaksanaan kegiatan; 2) fungsi sosialisasi; 3) fungsi pelayanan; 4) fungsi psikologis; dan 5) fungsi ekonomis. Fungsi pelaksanaan kegiatan adalah kecukupan 'ruang dalam' sarusun/rumah dalam menampung atau memfasilitasi kegiatan seluruh anggota keluarga penghuni di dalam rumah/sarusun. Makin kecil luas rumah/sarusun, makin banyak kegiatan keluarga yang tidak tertampung 
sehingga perlu pengaturan penggunaan ruang dalam rumah/sarusun atau pengaturan jadwal pelaksanaan kegiatan anggota keluarga secara bergiliran. Makin kecil ukuran rumah/sarusun biasanya makin banyak kegiatan yang tumpah ke luar sehingga menimbulkan makin besar intensitas interaksi dengan tetangga yang dapat bersifat positif maupun negatif terhadap harmoni sosial antarpenghuni perumahan dimaksud.

Fungsi sosialisasi adalah fasilitasi suatu perumahan dalam interaksi sosial antarpenghuni. Di perumahan, fungsi sosialisasi meliputi pemanfaatan teras depan rumah/sarusun serta berbagai fasilitas sosial-budaya untuk pertemuan. Saling interaksi antarpenghuni dapat mengarah pada pembentukan ikatan yang makin kokoh di satu sisi dan di sisi lain dapat menjadi titik mula terjadinya konflik. Fasilitas seperti taman, tempat olah raga, ruang serba guna, tempat parkir, dan lain-lain memfasilitasi interaksi sosial warga penghuni. Fungsi pelayanan meliputi berfungsinya fasilitas dan utilitas yang ada di perumahan yang memudahkan penghuni dalam melakukan kegiatan. Jadi fungsi pelayanan dirasakan fungsinya oleh penghuni sebagai individu, yang dapat dibedakan dengan fungsi sosialisasi yang dirasakan oleh penghuni sebagai kelompok. Semua jenis fasilitas yang tersedia di perumahan dengan fungsi melayani segala kegiatan penghuni di dalam pemenuhan kebutuhan hidupnya dimasukan sebagai fungsi pelayanan. Sementara utilitas yang meliputi kondisi jaringan air bersih, listrik, gas, drainase dan air limbah, serta pengelolaan sampah penting dalam memfasilitasi pelaksanaan berbagai kegiatan penghuni. Fasilitas dan utilitas membutuhkan pemeliharaan bersama, terutama lebih terasa di rumah susun. Kondisi fasilitas dan utilitas yang terganggu dapat merangsang terjadinya interaksi antarpenghuni, baik ke arah keakraban maupun perselisihan. Fungsi psikologis adalah kondisi perumahan dalam memberi rasa betah, rasa aman, serta privasi bagi penghuninya sehingga merasa terbebas dari gangguan bau, bising, keramaian, dan lain-lain. Fungsi ekonomi adalah kondisi perumahan terkait dengan kemampuan daya beli penghuni di dalam memenuhi berbagai biaya yang menyangkut hunian (seperti cicilan/sewa, iuran kebersihan, keamanan, retribusi utilitas) dan penyediaan kesempatan untuk berusaha kepada penghuni. Untuk mengukur kondisi fungsional perumahan ini digunakan indikator dan daftar pertanyaan yang digunakan oleh Wiranegara (2015) dengan beberapa penyesuaian agar cocok untuk kepentingan membandingkan antara kondisi fungsional perumahan susun dan perumahan tapak.

\section{Pengaruh kondisi lingkungan hunian terhadap harmoni sosial penghuninya}

Lingkungan fisik hunian dipandang sebagai setting bagi kegiatan manusia yang dapat bersifat inhibitting atau facilitating, yakni sifatnya dapat menghambat atau mempermudah, tidak menentukan ataupun menimbulkan aktivitas (Rapoport, 1977). Perumahan yang berkualitas buruk dapat diasosiasikan dengan terjadinya sikap mental yang buruk, serta cenderung menimbulkan sikap-sikap sosial yang buruk pula seperti tindakan-tindakan immoral, tidak bertanggungjawab, jahat, dan lain-lain (Soemirat, 1986). Berdasarkan hal tersebut diperlukan lingkungan fisik hunian yang supportive/mendukung ke arah peningkatan kualitas hidup penghuni, baik sebagai individu maupun sebagai kelompok seperti terciptanya harmoni sosial yang tinggi.

Pengaruh kondisi lingkungan hunian terhadap hubungan sosial penghuninya secara umum dan harmoni sosial secara khusus ditunjukkan oleh berbagai hasil penelitian berikut:

1. Pengaruh kondisi lingkungan fisik terhadap integrasi ketetanggaan merupakan gagasan Taman Dato'Harun yang menunjukkan bahwa 100\% responden mengetahui tetangganya, $99 \%$ bekerjasama dalam kegiatan komunitas, $85 \%$ merasa aman, $72 \%$ merasa bahwa RT (rukun tetangga) membantu mencegah kejahatan dan penyimpangan sosial, serta komunitas sangat puas terhadap RT dan merasa bahwa 
kegiatan-kegiatan telah membantu memperkuat hubungan yang positif dalam komunitas (Karim \& Rashid, 2017).

2. Hubungan sosial di rusun Pulo Gadung tetap intim di antara para pemilik seperti sebelumnya ketika tinggal di kampung: saling memberi salam, berkunjung ke tetangga, pergi ke luar bersama-sama, meminjam barang, mengirim makanan, gosip, urusan pribadi; ikatan komunal tetap hidup. Sementara penyewa yang berasal dari luar, kurang terintegrasi ke dalam kehidupan di rusun (Tampubolon, 1999).

3. Kondisi sosial komunitas rumah susun Bidaracina yang berasal dari bermacam-macam etnik namun dapat menjalin hubungan sosial yang cukup harmonis disebabkan oleh persamaan ikatan perasaan, mereka menempati unit hunian yang sama (tipe 18). Hubungan ketetanggaan ditandai dengan saling menyapa, ngobrol bersama di teras rumah, saling kunjung, menjaga hubungan baik tidak sampai cekcok, saling pengertian, saling menghormati, kegiatan saling menolong dalam hal musibah kematian, solidaritas tetangga tanpa memperhatikan asal-usul; memberi bantuan tenaga, materi, uang kepada tetangga yang hajatan; berkunjung menengok yang sakit jika diberitahu; kegiatan keagamaan meliputi ibadah bersama di mesjid di lingkungan rusun, membangun majelis taklim dari kaum ibu (Kusgiyarto, 2000).

4. Integrasi sosial di perumahan kelompok masyarakat berpendapatan rendah di Selangor, Malaysia terutama ditentukan oleh usia, etnik, lokasi, serta ikatan dan kepuasan atas tempat tinggal (Hashim, 2003).

5. Kondisi fisik yang berbeda - beda di masing -masing lingkungan rumah susun akan mempengaruhi kondisi kohesi sosial. Domain kohesi sosial meliputi kelekatan tempat (place attachment), dukungan sosial (functional social support), dan aktifitas/kegiatan kewargaan (civic activities) yang berbeda secara signifikan di antara lingkungan perumahan Rumah Susun Sukaramai Medan (Ichsan \& Blauw, 2011).

Baik di perumahan susun maupun di perumahan tapak dapat dijumpai masalah harmoni sosial. Penelitian ini mengidentifikasi perbedaan harmoni sosial antara penghuni rumah susun dengan penghuni rumah tapak, serta mengidentifikasi unsur-unsur lingkungan hunian yang mempengaruhi harmoni sosial pada dua tipe perumahan dimaksud. Pengaruh kondisi fungsional lingkungan perumahan terhadap harmoni sosial diperlihatkan pada kerangka konsep pada Gambar 1. Unsur-unsur lingkungan fisik perumahan yang mempengaruhi harmoni sosial penghuninya dikelompokkan berdasarkan fungsinya, meliputi: fungsi fasilitasi pelaksanaan kegiatan, fungsi sosialisasi, fungsi pelayanan, fungsi psikologis, dan fungsi ekonomi. Pengaruh unsur-unsur ini pada harmoni sosial diuji baik untuk perumahan tapak maupun perumahan susun.

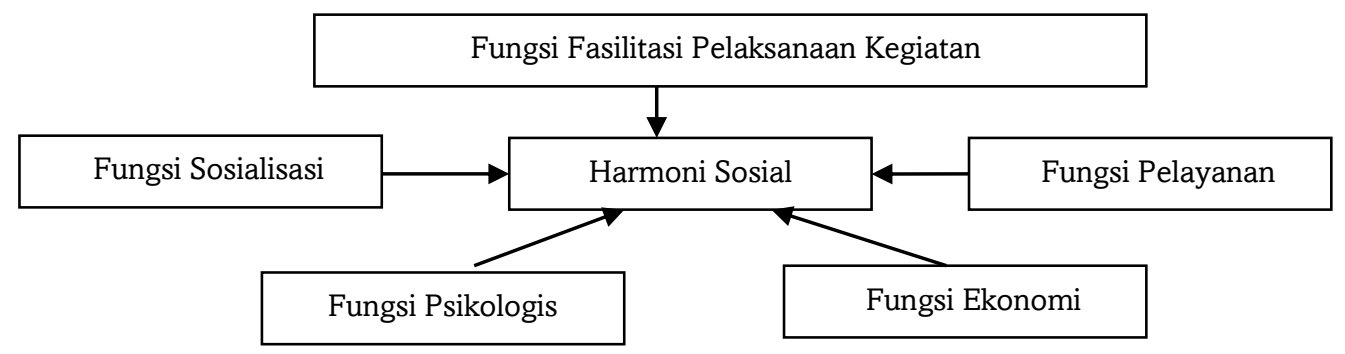

Gambar 1. Kerangka Konsep Pengaruh Kondisi Fungsional Perumahan pada Harmoni Sosial 


\section{METODE}

Tujuan penelitian ini adalah teridentifikasinya perbedaan harmoni sosial di dua tipe perumahan dan teridentifikasinya unsur fungsional lingkungan perumahan yang mempengaruhinya. Variabel harmoni sosial diukur dari tiga dimensi, yaitu harmoni dalam nilai, harmoni dalam perasaan, dan harmoni dalam tindakan. Sementara unsur-unsur lingkungan dilihat dari dimensi fungsionalnya yang meliputi fungsi fasilitasi pelaksanaan kegiatan, fungsi sosialisasi, fungsi pelayanan, fungsi psikologi, dan fungsi ekonomi, seperti diperlihatkan pada kerangka konsep pada Gambar 1. Dalam penelitian ini dianalisis pengaruh ke lima fungsi ini terhadap harmoni sosial di dua tipe perumahan di kawasan Tebet.

Desain penelitian yang cocok untuk penelitian ini adalah survey-angket. Pertanyaan angket berbentuk pernyataan terukur yang menggunakan skala Likert yang terdiri atas lima pilihan jawaban: sangat cocok, cocok, netral, tidak cocok, serta sangat tidak cocok. Pada skoring jawaban, nilai tertinggi diberikan pada kategori sangat cocok atau sangat tidak cocok bergantung pada jenis pernyataannya. Pernyataan yang sifatnya positif nilai tertinggi ada pada kategori sangat cocok. Sementara untuk pernyataan negatif, nilai tertinggi terletak pada kategori sangat tidak cocok.

Populasi dalam penelitian ini adalah lingkungan hunian dalam skala rukun tetangga dimana umumnya merupakan ruang tempat terjadinya harmoni sosial, karena interaksi tatap muka paling memungkinkan terjadi pada skala ini. Karakteristik populasi yang hendak diteliti meliputi kondisi fungsional rumah susun, kondisi fungsional rumah tapak, dan harmoni sosial penghuninya.

Lokus penelitian adalah RT 11/RW 07, Kelurahan Tebet Barat bagi sampel perumahan tapak, dan Rumah Susun Sederhana Milik (rusunami) Harum Tebet RT 01/RW 08. Ke dua lokasi perumahan ini berada di Kawasan Tebet, Kota Jakarta Selatan, Provinsi DKI Jakarta. Terdapat sejumlah 80 kepala keluarga di perumahan tapak RT 11/RW 07, dan 80 kepala keluarga di Blok 1/RT 01 rusunami Harum Tebet sehingga seluruhnya dijadikan sampel. Disebarkan sebanyak 160 angket kepada seluruh kepala keluarga di perumahan tapak RT 11/RW 07 dan rusunami Harum Tebet di Blok 1/RT 01. Angket ditujukan kepada responden yang merupakan anggota keluarga penghuni baik penghuni di perumahan tapak maupun perumahan rusun yang dianggap paling mengetahui kondisi sosial dan kondisi lingkungan perumahannya. Waktu pelaksanaan survey-angket dilakukan selama satu bulan terhitung dari tanggal 1 Mei 2016 sampai dengan tanggal 30 Mei 2016.

Teknik analisis menggunakan uji $\mathrm{T} / \mathrm{Z}$ untuk melihat perbedaan harmoni sosial penghuni rumah tapak dengan penghuni rumah susun, uji regresi dan uji Chi square untuk melihat hubungan antar variabel penelitian.

\section{ANALISIS DAN PEMBAHASAN}

Konteks dari harmoni sosial adalah adanya keragaman sosial. Keragaman sosial penghuni perumahan dapat digambarkan berdasarkan tingkat pendidikan, agama, suku, jenis pekerjaan, dan tingkat pendapatan. Berdasarkan tingkat pendidikan terakhir responden, keragamannya di rumah tapak lebih tinggi. Mayoritas penghuni rumah tapak dan rumah susun berpendidikan SMA. Penghuni berpendidikan lebih tinggi dari SMA di rusun relatif lebih tinggi persentasenya dibanding penghuni rumah tapak. Berdasarkan agama, penghuni rumah susun lebih variatif. Berdasarkan asal suku, penghuni rumah susun menunjukkan asal suku yang lebih beragam dibanding penghuni rumah tapak. Mayoritas suku di ke dua tipe perumahan sama, yakni suku Jawa, Sunda, dan Betawi. Berdasarkan jenis pekerjaan, penghuni di rumah susun lebih variatif. Berdasarkan tingkat pendapatan (yang didekati dari tingkat pengeluaran), baik penghuni rumah tapak maupun penghuni rumah susun menunjukkan adanya keragaman. Di rumah susun golongan pengeluaran 
tertinggi lebih tinggi persentasenya (30\%) dibanding dengan di rumah tapak (15\%). Sementara pada golongan pengeluaran paling rendah, di rumah tapak persentasenya lebih tinggi. Secara umum, dapat disimpulkan bahwa penghuni rusun menunjukkan tingkat keragaman sosial yang lebih tinggi dibanding penghuni rumah tapak.

Gambaran terkait hunian dapat diuraikan sebagai berikut. Status kepemilikan hunian yang ditempati di perumahan tapak mayoritas berstatus milik sendiri, sementara di rumah susun mayoritas adalah sewa/kontrak walaupun masuk kategori rusunami. Hanya tersisa 27,5\% penghuni yang berstatus milik sendiri. Artinya, sebagian besar unit rusunami (rumah susun sederhana milik) Harum Tebet telah disewakan atau dikontrakan oleh pemiliknya. Bergantinya penghuni di rumah susun dapat berpengaruh pada proses terbentuknya ikatan antarpenghuni. Di samping tingkat keragaman sosial yang lebih tinggi di rusun, juga terdapat gap antara penghuni lama dengan penghuni baru, sehingga tantangan bagi terwujudnya harmoni sosial di rusun lebih besar.

Berdasarkan lama tinggal, penghuni rumah tapak mayoritas $(91,25 \%)$ telah menetap lebih dari 15 tahun, sementara penghuni rumah susun mayoritas lama menetap antara 1115 tahun. Hal ini sesuai dengan usia perumahan tapak yang lebih dulu ada, sedangkan rumah susun dibangun kemudian. Tingginya persentase penghuni rumah susun yang lama tinggalnya 0-5 tahun menunjukkan banyaknya penghuni baru atau tingginya pergantian penghuni di rusun. Hasil ini cocok dengan gambaran tentang status hunian yang lebih banyak sebagai penyewa/pengontrak di rusun. Pada ke dua tipe perumahan, alasan penghuni untuk tinggal dan menetap di perumahan Tebet adalah karena mudah mencapai angkutan umum dengan persentasi terbesar. Alasan lainnya adalah dekat dengan tempat kerja dan atau waktu tempuh ke tempat kerja kurang dari 30 menit. Jadi, alasan utama menghuni di kawasan Tebet ini terkait dengan aksesibilitas terutama ke tempat kerja.

Berikut gambaran kondisi fungsional rumah tapak dan rumah susun yang meliputi fungsi fasilitasi pelaksanaan kegiatan, fungsi sosialisasi antarpenghuni, fungsi pelayanan kepada penghuni, fungsi psikologis, dan fungsi ekonomi. Fungsi fasilitasi pelaksanaan kegiatan terkait dengan fungsi masing-masing unit hunian kepada penghuninya dalam pelaksanaan kegiatan anggota keluarga penghuni yang bergantung pada luas unit hunian dan ukuran keluarganya. Luas unit rumah tapak lebih bervariasi, mulai dari $16 \mathrm{~m} 2$ hingga $136 \mathrm{~m} 2$. Sementara, luas hunian di rusun semua sama, yaitu $21 \mathrm{~m} 2$ (tipe 21). Luas rumah tapak di Tebet umumnya lebih luas karena umumnya memiliki dua lantai. Ukuran keluarga penghuni di rumah tapak dan di rumah susun pada umumnya berjumlah 3-4 orang. Dengan demikian, kesesakan di rumah susun lebih tinggi dibanding rumah tapak. Hal ini karena rata-rata jumlah penghuni per luas bangunan hunian lebih tinggi di rumah susun. Akibatnya, fungsi fasilitasi pelaksanaan kegiatan di rusun lebih rendah dibanding dengan di rumah tapak. Lihat Tabel 1.

Tabel 1 Fungsi Fasilitasi Pelaksanaan Kegiatan

\begin{tabular}{lcccc}
\hline \multirow{2}{*}{ Indikator } & \multicolumn{2}{c}{$\begin{array}{l}\text { Rumah Tapak } \\
\text { Skore }\end{array}$} & Kategori & \multicolumn{2}{c}{ Rumah Susun } \\
Skore & Kategori \\
\hline $\begin{array}{l}\text { Rumah terasa sempit, tidak semua kegiatan anggota } \\
\text { keluarga dapat dilaksanakan dengan wajar (tanpa }\end{array}$ & & & & \\
$\begin{array}{l}\text { gangguan) } \\
\begin{array}{l}\text { Dapat memanfaatkan ruangan di dalam rumah untuk } \\
\text { menerima tamu }\end{array}\end{array}$ & 285 & Sedang & 173 & Rendah \\
$\begin{array}{l}\text { Pemanfaatan depan rumah untuk menyimpan barang } \\
\text { yang tidak tertampung dalam rumah }\end{array}$ & 327 & Tinggi & 196 & Sedang \\
Fungsi fasilitasi pelaksanaan kegiatan & 245 & Sedang & 142 & Rendah \\
\hline
\end{tabular}

Sumber: Hasil Skoring, 2016

Fungsi pelayanan adalah berfungsinya pelayanan fasilitas dan utilitas perumahan kepada penghuni yang diukur melalui tiga indikator. Fasilitas di perumahan (susun dan 
tapak) meliputi: taman, tempat olah raga, ruang serba guna, masjid/mushola, posyandu, taman kanak-kanak, warung, warteg dan lain-lain. Utilitas perumahan (susun dan tapak) meliputi: jaringan listrik, jaringan air bersih, penerangan lampu jalan, dan lain-lain. Secara keseluruhan fungsi pelayanan perumahan yang terdiri atas pelayanan fasilitas dan utilitas diperlihatkan pada Tabel 2. Baik di perumahan tapak maupun di rumah susun, secara keseluruhan fungsi pelayanan fasilitas dan utilitas adalah sama (tinggi).

Tabel 2 Fungsi Pelayanan Perumahan

\begin{tabular}{llccc}
\hline \multicolumn{1}{c}{ Indikator } & \multicolumn{2}{c}{ Rumah Tapak } & \multicolumn{2}{c}{ Rumah Susun } \\
& Skore & Kategori & Skore & Kategori \\
\hline Ketersediaan fasilitas memadai & 351 & Tinggi & 346 & Tinggi \\
Ketersediaan pelayanan utilitas & 363 & Tinggi & 391 & Tinngi \\
Kualitas pelayanan utilitas & 361 & Tinggi & 210 & Sedang \\
Fungsi pelayanan fasilitas dan utilitas & 1075 & Tinggi & 947 & Tinggi \\
\hline
\end{tabular}

Sumber: Hasil Skoring, 2016

Fungsi sosialisasi dalam perumahan adalah penting karena fungsi tersebut berkaitan dengan interaksi antarpenghuni. Fungsi sosialisasi dilihat dari dua indikator, yakni pemanfaatan fasilitas sosial untuk berbagai kegiatan sosial yang dapat berpengaruh pada penyatuan warga dan pemanfaatan jalan/koridor depan rumah/sarusun untuk interaksi sosial. Secara keseluruhan, fungsi sosialisasi pada rumah tapak termasuk ke dalam kategori 'tinggi', sedangkan pada rumah susun termasuk ke dalam kategori 'sedang', seperti diperlihatkan pada Tabel 3. Jadi, fungsi sosialisasi lebih tinggi di rumah tapak dibandingkan dengan di rumah susun.

Tabel 3 Fungsi Sosialisasi Perumahan

\begin{tabular}{lcccc}
\multicolumn{1}{c}{ Indikator } & \multicolumn{2}{c}{ Rumah Tapak } & \multicolumn{2}{c}{ Rumah Susun } \\
& Skore & Kategori & Skore & Kategori \\
\hline $\begin{array}{l}\text { Pemanfaatan fasilitas sosial dengan baik untuk } \\
\text { kegiatan sosial (pengajian di masjid/musholah, }\end{array}$ & & & & \\
$\begin{array}{l}\text { pertandingan olahraga di lapangan/taman, rapat } \\
\text { karang taruna, dll) }\end{array}$ & 375 & Tinggi & 220 & Rendah \\
$\begin{array}{l}\text { Pemanfaatan jalan depan rumah untuk interaksi } \\
\text { sosial seperti tegur sapa, mengobrol, menggosip, }\end{array}$ & & & & \\
dan lain-lain & 328 & Tinggi & 318 & Sedang \\
Fungsi sosialisasi perumahan & 703 & Tinggi & 538 & Sedang \\
\hline
\end{tabular}

Sumber: Hasil Skoring, 2016

Tabel 4 Fungsi Psikologis Perumahan

\begin{tabular}{|c|c|c|c|c|}
\hline \multirow{2}{*}{ Indikator } & \multicolumn{2}{|c|}{ Rumah Tapak } & \multicolumn{2}{|c|}{ Rumah Susun } \\
\hline & Skore & Kategori & Skore & Kategori \\
\hline Kepadatan penghuni dirasa mengganggu & 275 & Sedang & 327 & Tinggi \\
\hline Merasa betah tinggal di lingkungan perumahan & 359 & Tinggi & 310 & Tinggi \\
\hline $\begin{array}{l}\text { Kondisi perumahan cukup aman bagi anak kecil dan } \\
\text { orang tua/lansia untuk tinggal dan beraktivitas } \\
\text { Tidak merasa khawatir rumah ditinggal dalam }\end{array}$ & 350 & Tinggi & 340 & Tinggi \\
\hline keadaan kosong & 318 & Tinggi & 217 & Sedang \\
\hline $\begin{array}{l}\text { Tidak merasa terganggu oleh bau, bising, keramaian, } \\
\text { dan lain-lain }\end{array}$ & 244 & Sedang & 348 & Tinggi \\
\hline Fungsi psikologis perumahan & 1546 & Tinggi & 1542 & Tinggi \\
\hline
\end{tabular}

Sumber: Hasil Skoring, 2016

Fungsi psikologis perumahan ditunjukkan oleh kondisi perumahan dalam memberi rasa betah, rasa aman, serta privasi kepada penghuninya. Privasi adalah kemampuan seseorang untuk menghindari gangguan yang datang dari lingkungan perumahan seperti gangguan bau, bising, keramaian, serta kepadatan penghuni. Fungsi psikologis perumahan 
penting karena dapat mempengaruhi perilaku penghuni, yang selanjutnya dapat berpengaruh pada baik buruknya tipe interaksi sosial yang terjadi. Fungsi psikologis diukur melalui lima indikator seperti diperlihatkan pada Tabel 4. Berdasarkan skore ke lima indikator, fungsi psikologis perumahan pada rumah tapak dan rumah susun menunjukkan kondisi yang sama, yakni termasuk kategori tinggi.

Fungsi ekonomi perumahan berkaitan dengan berbagai biaya hunian (seperti cicilan, iuran kebersihan, keamanan, retribusi utilitas) yang berada dalam jangkauan kemampuan daya beli penghuni dan ketersediaan kesempatan berusaha kepada penghuni. Berdasarkan ke dua indikator tersebut, fungsi ekonomi perumahan pada dua tipe perumahan berkategori tinggi. Lihat pada Tabel 5.

Tabel 5 Fungsi Ekonomi Perumahan

\begin{tabular}{lcccc}
\hline \multicolumn{1}{c}{ Indikator } & \multicolumn{2}{c}{ Rumah Tapak } & \multicolumn{2}{c}{ Rumah Susun } \\
& Skore & Kategori & Skore & Kategori \\
\hline Semua biaya hunian masih terjangkau & 372 & Tinggi & 363 & Tinggi \\
Tersedia tempat berusaha bagi penghuni & 267 & Sedang & 400 & Tinggi \\
Fungsi ekonomi perumahan & 639 & Tinggi & 763 & Tinggi \\
\hline
\end{tabular}

Sumber: Hasil Skoring, 2016

Berikut diuraikan tentang harmoni sosial. Harmoni sosial diukur melalui tiga dimensi, yaitu harmoni dalam nilai, harmoni dalam perasaan, dan harmoni dalam tindakan. Harmoni dalam nilai meliputi sepuluh nilai harmoni yang selanjutnya dijabarkan ke dalam 19 buah indikator. Hasil pada Tabel 6 menunjukkan bahwa harmoni dalam nilai di rumah susun lebih rendah dibanding dengan di rumah tapak.

Tabel 6 Tingkat Harmoni dalam Nilai di Perumahan

\begin{tabular}{lll}
\hline Harmoni dalam Nilai & Rumah Tapak & Rumah Susun \\
\hline Harmoni dalam Nilai Rendah & $9,08 \%$ & $56,05 \%$ \\
Harmoni dalam Nilai Sedang & $90,92 \%$ & $43,95 \%$ \\
Harmoni dalam Nilai Tinggi & $0,00 \%$ & $0,00 \%$ \\
Total & $100,00 \%$ & $100,00 \%$ \\
\hline
\end{tabular}

Sumber: Hasil Tabulasi Angket, 2016

Harmoni dalam perasaan diukur dengan menggunakan sepuluh indikator. Hasil pada Tabel 7 menunjukkan harmoni dalam perasaan di rumah susun lebih rendah dibanding dengan di rumah tapak.

Tabel 7 Tingkat Harmoni dalam Perasaan di Perumahan

\begin{tabular}{lll}
\hline Harmoni dalam Perasaan & Rumah Tapak & Rumah Susun \\
\hline Harmoni dalam Perasaan Rendah & $12,75 \%$ & $100,00 \%$ \\
Harmoni dalam Perasaan Sedang & $87,25 \%$ & $0,00 \%$ \\
Harmoni dalam Perasaan Tinggi & $0,00 \%$ & $0,00 \%$ \\
Total & $100,00 \%$ & $100,00 \%$ \\
\hline
\end{tabular}

Sumber: Hasil Tabulasi Angket, 2016

Tabel 8 Tingkat Harmoni dalam Tindakan di Perumahan

\begin{tabular}{lll}
\hline Harmoni dalam Tindakan & Rumah Tapak & Rumah Susun \\
\hline Harmoni dalam Tindakan Rendah & $8,30 \%$ & $79,20 \%$ \\
Harmoni dalam Tindakan Sedang & $91,70 \%$ & $20,80 \%$ \\
Harmoni dalam Tindakan Tinggi & $0,00 \%$ & $0,00 \%$ \\
Total & $100,00 \%$ & $100,00 \%$ \\
\hline
\end{tabular}

Sumber: Hasil Tabulasi Angket, 2016 
Harmoni dalam tindakan dilihat dari kebersamaan dalam menghidupkan kegiatan sosial (koperasi/nonkoperasi), mengadakan kas kesejahteraan sosial, membina generasi muda, memelihara kebiasaan baik, kebiasaan saling tegur, memelihara kebiasaan kerjabakti. Selanjutnya dijabarkan ke dalam sebelas indikator. Harmoni dalam tindakan di rumah susun lebih rendah dibanding dengan di rumah tapak, lihat Tabel 8.

Tabel 9 memperlihatkan bahwa harmoni sosial penghuni di rumah susun lebih rendah dibanding dengan harmoni sosial di rumah tapak. Jadi, terdapat perbedaan tingkat harmoni sosial antara penghuni rusun dengan penghuni rumah tapak.

Tabel 9 Tingkat Harmoni Sosial

\begin{tabular}{lll}
\hline Dimensi Harmoni Sosial & Rumah Tapak & Rumah Susun \\
\hline Harmoni dalam Nilai & Sedang & Rendah \\
Harmoni dalam Perasaan & Sedang & Rendah \\
Harmoni dalam Tindakan & Sedang & Rendah \\
Harmoni Sosial & Sedang & Rendah \\
\hline
\end{tabular}

Adanya perbedaan antara harmoni sosial penghuni di rumah tapak dengan di rumah susun dapat ditunjukkan pula melalui nilai rata-ratanya, seperti diperlihatkan pada Tabel 10. Nilai rata - rata harmoni sosial penghuni rumah tapak lebih besar daripada nilai ratarata harmoni sosial penghuni rumah susun.

Tabel 10 Perbedaan Harmoni Sosial Penghuni Rumah Tapak dan Penghuni Rumah Susun

\begin{tabular}{cccccc}
\hline & Jenis Hunian & N & Mean & Std. Deviation & Std. Error Mean \\
\hline Harmoni & Rumah Tapak & 80 & 4.3496 & .37709 & .04216 \\
Sosial & Rumah Susun & 80 & 3.0734 & .16327 & .01825 \\
\hline
\end{tabular}

Sumber: Hasil Analisis, 2016

Tabel 11 Uji Perbedaan Harmoni Sosial di Rumah Tapak dan di Rumah Susun

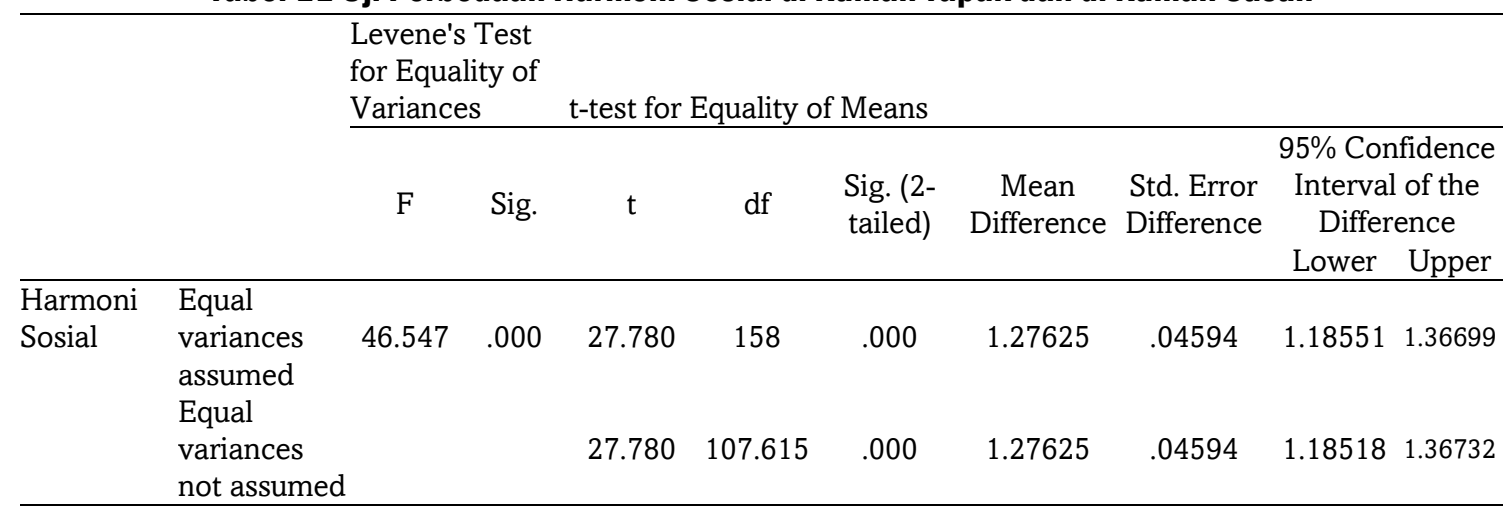

Sumber: Hasil Analisis, 2016

Uji statistik untuk menunjukkan adanya perbedaan harmoni sosial antara penghuni di rumah tapak dengan penghuni di rumah susun diperlihatkan pada Tabel 11. Pada kolom (sig.) diperoleh hasil yang signifikan dengan nilai sig.0,000, baik uji F maupun uji t. Dengan nilai probabilitas yang lebih kecil dari 0,05 , maka $\mathrm{H}_{0}$ ditolak atau ke dua varians populasi harmoni sosial penghuni rumah tapak dengan harmoni sosial penghuni rumah susun adalah berbeda. Jadi, dapat disimpulkan bahwa terdapat perbedaan harmoni sosial antara penghuni di rumah tapak dengan harmoni sosial di rumah susun.

Untuk menentukan unsur-unsur kondisi fungsional rumah tapak dan rumah susun yang mempengaruhi harmoni sosial penghuninya digunakan uji regresi. Kerangka konsep yang diuji adalah harmoni sosial penghuni perumahan dipengaruhi oleh kondisi 
fungsionalnya yang meliputi fungsi fasilitasi pelaksanaan kegiatan, fungsi sosialisasi, fungsi pelayanan, fungsi psikologis, dan fungsi ekonomi.

Berdasarkan uji regresi diperoleh persamaan harmoni sosial sebagai berikut:

HS-tapak $=1,405+0,111 \mathrm{FPk}+0,104 \mathrm{FS}+0,95 \mathrm{FP}+0,328 \mathrm{FPs}+0,115 \mathrm{FE}$

HS-rusun $=1,869-0,021 \mathrm{FPk}-0,033 \mathrm{FS}+0,114 \mathrm{FP}-0,075 \mathrm{FPs}+0,071 \mathrm{FE}$

Keterangan:

$\begin{array}{ll}\mathrm{HS} & =\text { Harmoni Sosial } \\ \mathrm{FPk} & =\text { Fasilitasi Pelaksanaan Kegiatan } \\ \mathrm{FS} & =\text { Fungsi Sosialisasi } \\ \mathrm{FP} & =\text { Fungsi Pelayanan } \\ \mathrm{FPs} & =\text { Fungsi Psikologis } \\ \text { FE } & =\text { Fungsi Ekonomi }\end{array}$

Pada rumah tapak, semua unsur kondisi fungsional berpengaruh positif terhadap harmoni sosial penghuninya. Artinya semakin tinggi nilai masing - masing unsur kondisi fungsional rumah tapak, maka semakin besar pula harmoni sosial penghuni di rumah tapak. Model di rumah tapak memiliki nilai $\mathrm{R}^{2}=0,394$. Artinya, harmoni sosial di rumah tapak sebesar 39,4\% ditentukan oleh ke lima kondisi fungsionalnya. Berdasarkan uji regresi/anova diperoleh nilai $F$ hitung sebesar 9,612 dengan tingkat signifikansi 0,000. Dengan angka probabilitas kurang dari 0,05, maka model regresi di rumah tapak adalah signifikan, artinya ke lima unsur kondisi fungsional rumah tapak dapat dipakai untuk memprediksi harmoni sosial penghuninya.

Pada persamaan regresi untuk rumah susun, hanya fungsi pelayanan dan fungsi ekonomi berpengaruh positif terhadap peningkatan harmoni sosial penghuni. Sementara fungsi fasilitasi pelaksanaan kegiatan, fungsi sosialisasi, dan fungsi psikologis berpengaruh negatif. Artinya, ke tiga fungsi tersebut tidak berpengaruh pada harmoni sosial di rumah susun. Alasannya, seperti dikemukakan oleh Bahri (2005) bahwa rumah susun tidak mampu memberikan pemecahan kebutuhan manusia penghuninya secara utuh, karena selama ini rumah susun dibangun atas dasar pertimbangan ekonomi (yakni finansial) dan teknis semata. Menurutnya rumah susun akan bermanfaat jika dipandang sebagi suatu usaha untuk menjawab kebutuhan penghuni dari berbagai aspek.

Dari dua persamaan regresi harmoni sosial di rumah tapak dan di rumah susun, dapat disimpulkan bahwa unsur kondisi fungsional perumahan yang berpengaruh positif pada harmoni sosial baik di rumah tapak maupun di rumah susun adalah fungsi pelayanan dan fungsi ekonomi. Dalam fungsi pelayanan yang mencakup ketersediaan fasilitas, penelitian Karim (2008) menunjukkan penghuni rumah susun di Shah Alam memiliki tingkat kesejahteraan lebih tinggi dibanding penghuni rumah susun di Klang karena tingkat kepuasannya lebih tinggi akibat faktor ketersediaan dan aksesibilitas fasilitas komunitas.

Fungsi pelayanan meliputi ketersediaan fasilitas yang memadai, ketersediaan utilitas, dan kualitas pelayanan utilitas. Fungsi pelayanan ini menjadi penting berpengaruh pada harmoni sosial di rumah tapak maupun di rumah susun seperti ditunjukkan oleh nilai koefisien yang positif. Untuk kasus rumah tapak nilai koefisiennya sangat tinggi 0,95 . Salah satu alasan yang dapat dikemukakan mengapa fungsi pelayanan berpengaruh pada harmoni sosial adalah sebagai berikut: kerukunan ataupun konflik sesama penghuni di perumahan umumnya terkait dengan kondisi pelayanan fasilitas dan utilitas. Hal ini lebih tampak di rumah susun. Utilitas sebagai bagian bersama dan fasilitas sebagai benda bersama menuntut kebersamaan di antara sesama penghuni rusun baik di dalam pemanfaatannya maupun pemeliharaannya. Tanpa kebersamaan akan dihadapi kesulitan di dalam menegakkan fungsi pelayanannya. Dengan baiknya fungsi pelayanan, hubungan sosial di antara mereka tidak mengganggu harmoni sosial.

Fungsi kedua yang mempengaruhi harmoni sosial di rumah tapak dan di rumah susun adalah fungsi ekonomi. Fungsi ekonomi meliputi ketersediaan tempat berusaha dan 
keterjangkauan berbagai biaya hunian. Salah satu ciri rendahnya harmoni sosial di perumahan adalah tercerai berainya penghuni seperti ditunjukkan oleh fenomena berpindahnya penghuni ke luar. Penyebab perpindahan ini di antaranya adalah tidak adanya tempat berusaha untuk mereka dan tidak terjangkaunya biaya-biaya yang menyangkut hunian.

Hasil tersebut dapat digunakan untuk menjelaskan pentingnya di dalam perencanaan kawasan perumahan khususnya untuk MBR untuk menyediakan tempat berusaha dan ketersediaan fasilitas dan utilitas yang berfungsi baik. Fungsi pelayanan dan fungsi ekonomi harus menjadi pertimbangan jika diinginkan terciptanya harmoni sosial. Fenomena keengganan masyarakat berpendapatan rendah direlokasi ke rumah susun adalah karena tidak tersedianya tempat berusaha untuk mereka dan belum berfungsinya fasilitas dan utilitas, dapat dijelaskan oleh hasil temuan di atas.

Agar terjamin ke dua fungsi tersebut berjalan dengan baik, maka peran pemerintah daerah menjadi penting baik sebagai pengawas, regulator, atau penyedia. Sebagai pengawas dapat diperankan oleh dinas atau SKPD terkait untuk senantiasa memonitor kondisi perumahan dalam hal berjalannya fungsi pelayanan dan fungsi ekonomi. Sebagai regulator dapat diperankan baik oleh pemerintah pusat maupun pemerintah daerah. Regulasi yang penting di dalam penyediaan fungsi pelayanan adalah selain adanya standar pelayanan minimum penyediaan fasilitas sosekbud dan utilitas perumahan, juga perlu aturan untuk pengawasannya atau monitoringnya. Sementara terkait dengan fungsi ekonomi adalah menyusun standar di dalam penyediaan ruang-ruang usaha. Terkait dengan peran sebagai penyedia berlaku baik untuk pemerintah pusat maupun pemerintah daerah. Tugas dan fungsi pemerintah pusat di bidang perumahan termasuk penyediaan. Hal ini sebagai upaya membantu pemerintah daerah yang masih terbatas baik dalam pendanaan maupun kemampuan sumber daya manusia aparat daerah di bidang perumahan.

Dalam rangka membangun harmoni sosial di perumahan, perlu penelitian lebih lanjut di dalam mengidentifikasi unsur-unsur fisikal perumahan secara detail yang terkait dengan fungsi pelayanan dan fungsi ekonomi yang cocok untuk masyarakat berpendapatan rendah, baik untuk perumahan tapak maupun perumahan susun.

\section{KESIMPULAN}

Simpulan penelitian ini adalah terdapat perbedaan harmoni sosial antara penghuni rumah tapak dengan penghuni rumah susun. Harmoni sosial penghuni rumah susun lebih rendah dibanding dengan harmoni sosial penghuni rumah tapak. Unsur-unsur yang berpengaruh pada harmoni sosial di ke dua tipe perumahan adalah fungsi pelayanan dan fungsi ekonomi. Untuk meningkatkan harmoni sosial agar terwujud komunitas yang berkelanjutan maka di dalam pembangunan perumahan agar pemerintah pusat sebagai regulator sekaligus penyedia perlu menegakkan fungsi pelayanan dan fungsi ekonomi di perumahan. Sementara pemerintah daerah berperan sebagai pengawas dan penyedia terkait dengan berjalannya fungsi pelayanan dan fungsi ekonomi perumahan yang ada di daerahnya. Penelitian lebih lanjut yang perlu dilakukan adalah terkait dengan identifikasi unsur-unsur fisikal perumahan untuk terlaksananya fungsi pelayanan dan fungsi ekonomi yang cocok bagi masyarakat berpendapatan rendah baik di perumahan tapak maupun di perumahan susun. 


\section{DAFTAR PUSTAKA}

Bahri, S. 2005. Rumah Susun sebagai Bentuk Budaya Bermukim Masyarakat Modern. Jurnal Sistem Teknik Industri 6(3):97-102.

https://s3.amazonaws.com/academia.edu.documents/37359858/Sistem_Teknik_Industri_Vol_6_No 3_Juli_2005.pdf?AWSAccessKeyId=AKIAIWOWYYGZ2Y53UL3A\&Expires=1512306203\&Signature= K1qFE1fqi\%2BLjuML\%2FT09gnYWA\%2BVA\%3D\&response-contentdisposition=inline $\% 3 B \% 20$ filename $\% 3 D J u r n a l \_U s u . p d f \# p a g e=101$

Budihardjo, E. 1997. Tata ruang perkotaan. Bandung: Penerbit Alumni.

Hashim, A.H. 2003. Residential Satisfaction and Sosial Integration in Public Low Cost Housing in Malaysia. Pertanika J.Soc. Sci \& Hum. 11(1):1-10. Universiti Putra Malaysia Press. https://www.researchgate.net/publication/35399979_Residential_satisfaction_and_social_integration_i n_public_low_cost_housing_in_Malaysia

Ichsan, F., \& Blauw, W. 2011. The Development of Social Cohesion in Public Housing A Study in A Flat Housing Project in Sukaramai, Medan (Master's thesis). Magister Perencanaan Kota \& Daerah, Universitas Gadjah Mada.

Karim, H.A (2008). The Satisfaction of Residents on Community Facilities in Shah Alam, Malaysia. Asian Social Science, 4(11):131-137. http://www.ccsenet.org/journal/index.php/ass/article/view/826

Karim, H.A (2012). Low Cost Housing Environment: Compromising Quality of Life? Procedia-Social and $\begin{array}{llll}\text { Behavioral Sciences. } & \text { Vol 35: } & \text { 44-53. }\end{array}$ http://www.sciencedirect.com/science/article/pii/S1877042812003734

Karim, H. A. \& Rashid, S. M. A. (2017). Community participation: Towards a safer housing environment. Asian Journal of Environment-Behaviour Studies, 2(2):39-51. https://aje-bs.e-iph.co.uk/index.php/ajEBs/article/view/176

Koentjaraningrat. (1977). Beberapa Pokok Antropologi Sosial. Jakarta: Penerbit Dian Rakyat.

Kusgiyarto. 2000. Pengembangan komunitas rumah susun: studi kasus rumah susun Bidaracina. Jakarta Timur. (Tesis). Universitas Indonesia, Jakarta.

Randy, M. 2013. Identifikasi Kemampuan dan Kemauan Membayar Sewa Masyarakat Berpenghasilan Rendah Terhadap Rumah Susun Sederhana Sewa dan Faktor-Faktor yang Mempengaruhinya. Journal of Regional and City Planning, 24(2), 95-108.

Rapport, A. 1977. Human aspect of urban form towards a man-environment approach to urban form and design. New York: Pergamon Press.

Soemirat, J. 1986. Pengaruh lingkungan perumahan terhadap kesehatan masyarakat. Jurnal Penelitian Pemukiman, Vol. II(1).

Tampubolon, L. 1999. People in the blocks: Neighbourly relations in the rumah susun Pulo Gadung, Jakarta. $\begin{array}{llllll}\text { Annual } & \text { Report } & 1999, & \text { p. } & \text { October } & 23,\end{array}$ http://rspas.anu.edu.au/booklets/anthropology/ant_AR_1999.pdf

Tjahjono, G. 2008. Permasalahan perancangan rumah susun sederhana milik (Rusunami). Paper presented in the Workshop on: Implementasi Kebijakan Penyelenggaraan Pembangunan Rumah Susun di Kawasan Perkotaan. Sponsored by the State Ministry of Public Housing. Jakarta 20-21 August 2008.

Undang-undang Nomor 20 Tahun 2011 tentang Rumah Susun.

Wiranegara, H.W et al. 2013. A Model of Environmental Harmony Towards Sustainable Walk-up Flats Community in Kemayoran $\quad$ http://www.iiste.org/Journals/index.php/RHSS/article/viewFile/6943/7080.

Wiranegara, H.W. 2015. Pengaruh Kondisi Rumah Susun pada Harmoni Sosial Penghuni di Rumah Susun Kemayoran. Laporan Penelitian, FTSP-Usakti. 